\title{
Publishing in Library Science Journals: A Test of the Olsgaard Profile*
}

\begin{abstract}
As a test of the universality of the Olsgaard profile of authorship characteristics in academic library journals, the gender, geographic location, and occupation of authors contributing to five journals of interest to special librarians were analyzed. The resulting data provide the basis for the construction of a profile of authorship characteristics in special library journals. This profile is compared to that produced by Olsgaard and Olsgaard, whose methodology this study replicates. This study shows that while female authors are consistently underrepresented in the literature of library science, they are published in greater proportion in special library periodicals than in the academic library periodicals sampled by the Olsgaards. This study essentially confirms the Olsgaards' findings with regard to geographic distribution and occupation of authors in library periodicals.
\end{abstract}

I N THEIR RECENT ARTICLE "Authorship in Five Library Periodicals," John N. and Jane Kinch Olsgaard reported the results of a bibliometric study that examined selected characteristics of authors published in library science journals. ${ }^{1}$ The characteristics under study were journal authors' sex, occupation, and geographic location. The Olsgaards sought evidence of publication bias by comparing authorship characteristics with the characteristics of the library science community as a whole.

The Olsgaards found that in the five journals studied, female authors were not represented in proportion to their numbers in the library profession. Thirty-four percent of

*This paper was supported by the U.S. Department of Energy under contract DE-ACO4-76DP-00789.

Martha C. Adamson is librarian, physical sciences and engineering, Technical Library, Air Force Weapons Laboratory, Kirtland AFB, New Mexico. Gloria J. Zamora is subject specialist, Technical Library, Sandia National Laboratories, Albuquerque, New Mexico. the authors in the journals studied were women, while 84 percent of all librarians are women. With regard to occupation, the Olsgaards found that the journals studied contained a "substantial number of articles by practicing librarians." 2 They also found that library science faculty members were represented in numbers greater than their proportion of the library population. In comparing the geographic distribution of authors in five library journals to the distribution of the United States population as a whole, the Olsgaards found that a disproportionately large number of authors were from the Northeast and Midwest, while the Southeast and Southwest were underrepresented.

\section{PROBLEM AND HyPOTHESIS}

The Olsgaards selected the five library periodicals in their study based upon the following criteria:

1. minimum ten-year publication history;

2. recognition as a "nationally known journal of library science"; ${ }^{3}$

3. article format; 
4. influence on the library profession;

5. "common trends in publishing." 4

The journals selected were:

College \& Research Libraries, V.29-38, 1968-77;

Library Journal, V.93-102, 1968-77;

Library Quarterly, V.38-47, 1968-77;

Library Trends, V.16-25, 1967-77;

$R Q$, V.7-16, 1968-77.

This article does not question the selection of these five journals for the Olsgaard study. Each journal quite clearly meets the criteria they stated. In the opinion of these authors, however, each journal also meets another, unstated criterion. Each is a journal that is of greater interest to librarians in institutions of higher learning or to library science faculty and students. We were concerned that rather than portraying the authorship patterns of library periodicals in general, the Olsgaards' study might be biased toward the authorship characteristics of academic librarianship.

To test the general applicability of the Olsgaards' authorship profile, a study was conducted using the Olsgaards' methodology. The research population selected was journals believed to be of interest to special librarians. Do authorship characteristics in special library periodicals differ from those found in the Olsgaard study? The intent in gathering additional data was to modify and enhance the evolving profile of authorship characteristics in library periodicals.

\section{METHODOLOGY}

With the Olsgaard criteria in mind, the following journals were selected for study:

Journal of the American Society for Information Science (ASIS), V.21-30, 197079

Law Library Journal (Law), V.62-71, 1969-78;

Bulletin of the Medical Library Association (MLA), V.57-66, 1969-78;

Online Review (Online), V.1-3, 1977-79;

Special Libraries (SL), V.61-70, 1970-79.

Online Review does not meet one of the prescribed qualifications because it does not have a ten-year publishing history. It was included in the study genre because it represents a new field in library periodicals, and an area of interest that is of growing influence in the special libraries community.
All articles for the years shown above were studied. As in the Olsgaard study, book reviews and letters to the editor were not included. The Olsgaard methodology was followed with respect to multiple authorship and occupation.*

Ambiguous or incomplete information in any data entry was assigned to an "indeterminate" category and was disregarded in statistical operations, which utilized the following formula:

$$
\begin{aligned}
& X=a^{\prime}(N-d) \text { where } X=\text { pecentage of spe- } \\
& \text { cific data entries; } \\
& a=\text { number of un- }
\end{aligned}
$$

\section{LIMITATIONS}

Analyzing authorship characteristics based only on the information provided by the typical library science journal is inherently risky. Most author information is sketchy and incomplete. In this regard, Online Review merits praise for the completeness of its author information, which includes the author's current preferred mailing address. The Journal of the American Society for Information Science has much room for improvement.

The regional designations adopted by the Olsgaards and continued in this study are those of the ALA Committee on the Accreditation of Graduate Library School Programs. These regional designations are, in the opinion of the authors, not always in agreement with common usage. For example, the ALA Committee on Accreditation considers Mississippi to be part of the Southwest region. Missouri, which was missing from the Olsgaards' regional listing, was added to the Midwest group. The committee's regional categories are as follows:

Northeast: Connecticut, Delaware, District of Columbia, Maine, Maryland, Mas-

*Each author was counted as one complete data entry, and each occupation was counted as one complete data entry. 
sachusetts, New Hampshire, New Jersey, New York, Pennsylvania, Rhode Island, Vermont.

Southeast: Alabama, Florida, Georgia, Kentucky, North Carolina, South Carolina, Tennessee, Virginia, West Virginia.

Midwest: Illinois, Indiana, Iowa, Kansas, Michigan, Minnesota, Missouri, Nebraska, North Dakota, Ohio, South Dakota, Wisconsin.

Southwest: Arizona, Arkansas, Louisiana, Mississippi, New Mexico, Oklahoma, Texas.

West: Alaska, California, Colorado, Hawaii, Idaho, Montana, Nevada, Oregon, Utah, Washington, Wyoming.

Because this study focused on special library journals, it was necessary to modify the Olsgaards' occupational categories to describe more accurately the contributors to these journals. The occupational sets for the two studies are compared as follows:

Olsgaard Study

Academic librarian

Public librarian

Other librarian

Library science faculty

Library science student

Other faculty

Nonlibrarian/

Nonacademic

The reader is cautioned not to make extensive occupational comparisons between the two studies. Because occupational categories in this study have been redefined, correlations drawn between the studies would be spurious. In this study, librarians and information specialists who work in libraries and information centers serving industry, business, research institutes, and government are defined as special librarians. Also counted as special librarians are academic librarians clearly identified as working in a separate subject collection in an academic library. For example, an author identified as "Reference Librarian, Engineering Library, Anywhere University." is counted as a special librarian, while an author identified as "Science Bibliographer, University of Anywhere Library" is counted as an academic librarian. Similarly, a "Technical Information Specialist, Technical Information Center, ABC Corp." appears as a special librarian, while "Technical Information Specialist, ABC Corp." is considered to be a private-sector occupation.

\section{RESUlts}

Female authors were not represented in proportion to their numbers in the special library community in any of the five journals studied. Female authors were published 9.3 percent more frequently in special library journals than in academic ones; however, females are 9.7 percent more prevalent in special librarianship than in academic librarianship (table 1). In the special library journals studied, 56.3 percent of the authors were male, while 43.7 percent were female. In two journals, Bulletin of the Medical Library Association and Online Review, female authors were actually in the majority, representing 56.9 percent and 59.3 percent of the authors, respectively. The Journal of the American Society for Information Science trailed in female authorship, with 23.5 percent (table 2).

The geographic distribution of authors in this study resembles quite closely that of the Olsgaards' study (table 3). Again, as in the Olsgaard study, the northeastern portion of the country is represented by a substantially larger percentage of articles than its percentage of the population, while the southeastern and southwestern regions are underrepresented. In special library journals, the midwestern region falls slightly below its expected publication rate, and the west slightly exceeds expectations. Just the opposite is shown in the Olsgaard study (figure 1).

TABLE 1

Comparative Author Gender Ratios

\begin{tabular}{lcc}
\hline & Male & Female \\
\hline $\begin{array}{l}\text { Authors in Olsgaard study } \\
\text { Academic librarians* }\end{array}$ & 65.6 & 34.4 \\
$\begin{array}{l}\text { Authors in special } \\
\text { library journals }\end{array}$ & 33.8 & 66.2 \\
$\begin{array}{l}\text { Special librarians* } \\
\text { National average }\end{array}$ & 56.3 & 43.7 \\
$\quad$ of all librarians* & 24.1 & 75.9 \\
\hline
\end{tabular}

-U.S. Department of Labor, Bureau of Labor Statistics, Library Manpotcer: A Study of Demand and Supply (Washington, D.C.: Govt. Print. Off., 1975). 
TABLE 2

Gender of Authors in Five Special Library Periodicals

\begin{tabular}{|c|c|c|c|c|c|c|c|}
\hline Journal & $\begin{array}{c}\text { Percentage } \\
\text { Male }\end{array}$ & $\begin{array}{c}\text { Percentage } \\
\text { Female }\end{array}$ & $N$ & - & $d$ & & \\
\hline ASIS & 76.5 & 23.5 & 777 & - & 126 & $=$ & 651 \\
\hline Law & 58.8 & 41.2 & 328 & - & 15 & $=$ & 313 \\
\hline$M L A$ & 43.1 & 56.9 & 710 & - & 53 & $=$ & 657 \\
\hline Online & 40.7 & 59.3 & 156 & - & 6 & $=$ & 150 \\
\hline$S L$ & 52.5 & 47.5 & 767 & - & 20 & $=$ & 747 \\
\hline Weighted average & 56.3 & 43.7 & & & & & \\
\hline
\end{tabular}

In seeking an explanation for the greater productivity of librarians in the northeastern region of the country, the authors investigated the possibility that this region might contain proportionally more library schools and consequently an atmosphere that stimulated scholarly pursuits both by academic librarians and their special librarian colleagues. Basing their distribution percentages on the fifty-seven ALA-accredited graduate library school programs located in the United States as of December 1978, the authors found that library schools were regionally distributed as shown in table $4 .^{5}$

Since library schools are nearly evenly distributed in relation to the population of librarians, the authors concluded that no positive correlation could be made between the distribution of library schools and the productivity of librarians in terms of authorship.

It is no surprise to find special librarian

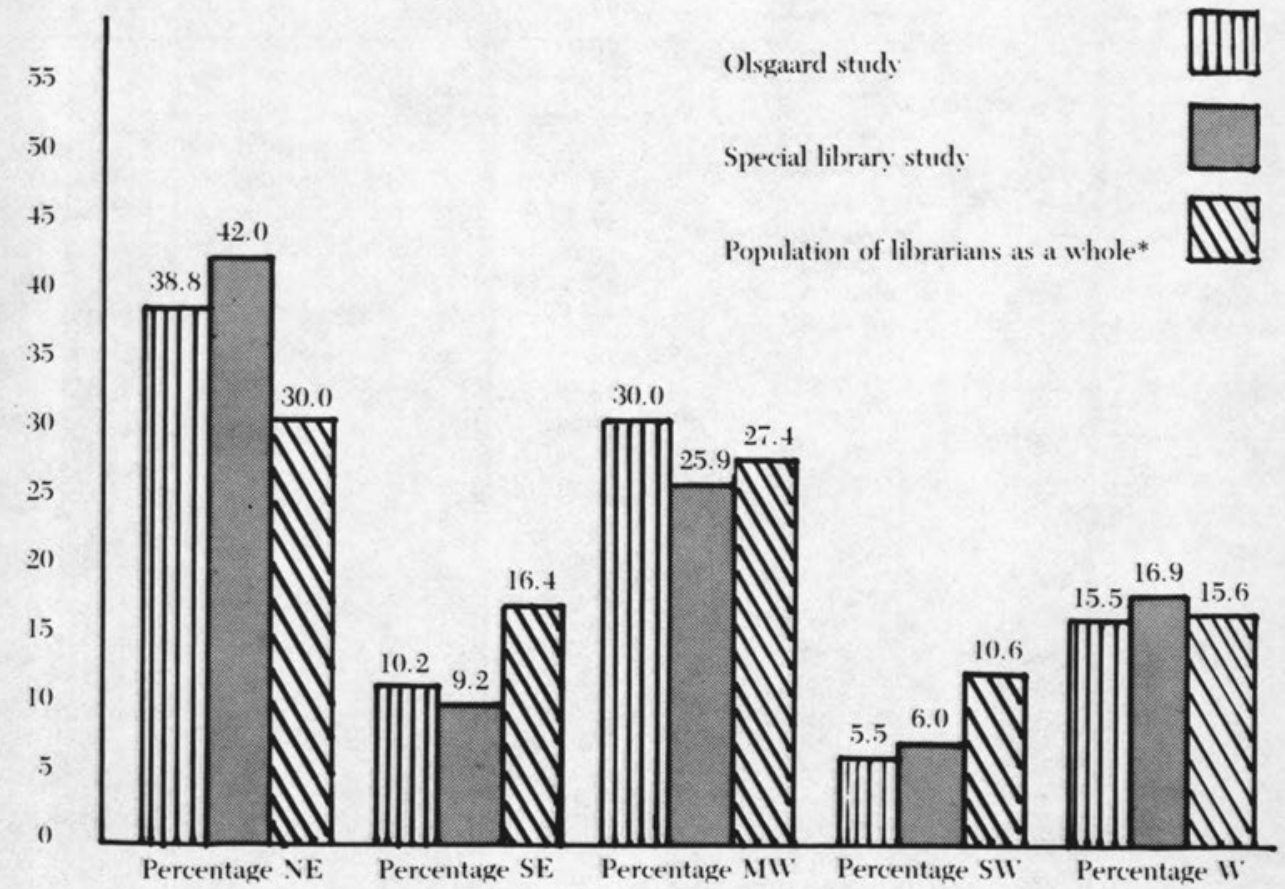

*U.S. Department of Labor. Bureau of Labor Statistics, Library Manpouer: A Study of Demand and Supply (Washington. D. C..: (iont. Print. Off. 1975).

Fig. 1

Comparative Geographic Distribution Ratios 
Test of the Olsgaard Profile / 239

TABLE 3

Geographic Distribution of Authors in Five Special Library Periodicals

\begin{tabular}{|c|c|c|c|c|c|c|c|c|c|c|}
\hline Journal & $\begin{array}{c}\text { Percentage } \\
\text { NE }\end{array}$ & $\begin{array}{c}\text { Percentage } \\
\text { SE }\end{array}$ & $\begin{array}{l}\text { Percentage } \\
\text { MW }\end{array}$ & $\begin{array}{l}\text { Percentage } \\
\text { SW }\end{array}$ & $\begin{array}{l}\text { Percentage } \\
\text { W }\end{array}$ & $N$ & - & $d$ & & \\
\hline ASIS & 50.1 & 7.3 & 24.3 & 4.7 & 13.6 & 781 & - & 163 & $=$ & 618 \\
\hline Law & 25.7 & 13.3 & 26.3 & 6.6 & 28.1 & 379 & - & 48 & $=$ & 331 \\
\hline$M L A$ & 37.1 & 12.5 & 30.0 & 8.6 & 11.8 & 754 & - & 43 & $=$ & 711 \\
\hline Online & 44.4 & 1.4 & 25.0 & 1.4 & 27.8 & 158 & - & 14 & $=$ & 144 \\
\hline$S L$ & 46.9 & 7.3 & 23.2 & 5.3 & 17.3 & 783 & - & 67 & $=$ & 716 \\
\hline Weighted average & 42.0 & 9.2 & 25.9 & 6.0 & 16.9 & & & & & \\
\hline
\end{tabular}

TABLE 4

Regional Distribution of Library Schools

\begin{tabular}{lccccc}
\hline & $\begin{array}{c}\text { Percentage } \\
\text { NE }\end{array}$ & $\begin{array}{c}\text { Percentage } \\
\text { SE }\end{array}$ & $\begin{array}{c}\text { Percentage } \\
\text { MW }\end{array}$ & $\begin{array}{c}\text { Percentage } \\
\text { SW }\end{array}$ & $\begin{array}{c}\text { Percentage } \\
\text { W }\end{array}$ \\
\hline $\begin{array}{l}\text { Library schools } \\
\begin{array}{l}\text { Population of } \\
\text { librarians as } \\
\text { a whole* }\end{array}\end{array}$ & 29.8 & 21.1 & 28.1 & 8.8 & 12.3 \\
\hline
\end{tabular}

-U.S. Department of Labor. Bureau of Labor Statistics, Library Manpotcer: A Study of Demand and Supply (Washington. D.C.: Goxt. Print. Off. (975), p. 7.

TABLE 5

Occupation of authors in Five Special Library Periodicals

\begin{tabular}{|c|c|c|c|c|c|c|c|c|c|c|c|c|}
\hline Journal & Academic & $\begin{array}{l}\text { Library } \\
\text { Science } \\
\text { Faculty }\end{array}$ & $\begin{array}{c}\text { Special } \\
\text { Librarian }\end{array}$ & $\begin{array}{c}\text { Other } \\
\text { Librarian }\end{array}$ & $\begin{array}{l}\text { Other } \\
\text { Faculty }\end{array}$ & $\begin{array}{c}\text { Informa- } \\
\text { tion } \\
\text { Supplier }\end{array}$ & $\begin{array}{l}\text { Private } \\
\text { Government }\end{array}$ & $\boldsymbol{N}$ & - & $d$ & & \\
\hline ASIS & 2.2 & 18.3 & 6.1 & 0.8 & 41.7 & 5.6 & 25.3 & 781 & - & 23 & $=$ & 758 \\
\hline Lau & 1.6 & 1.1 & 62.5 & 2.5 & 21.9 & 1.1 & 9.3 & 379 & - & 13 & $=$ & 366 \\
\hline MLA & 2.6 & 6.8 & 68.6 & 4.3 & 12.3 & 0.8 & 4.6 & 754 & - & 14 & $=$ & 740 \\
\hline Online & 8.3 & 3.2 & 26.7 & 1.3 & 3.2 & 32.5 & 24.8 & 158 & - & 1 & $=$ & 157 \\
\hline$S L$ & 13.6 & 11.4 & 43.8 & 5.6 & 5.4 & 3.7 & 16.4 & 783 & - & 4 & $=$ & 779 \\
\hline Weighted average & 5.8 & 10.3 & 41.6 & 3.3 & 19.1 & 4.7 & 15.3 & & & & & \\
\hline
\end{tabular}

authors heavily represented in this study. They constitute 41.6 percent of the authors in the five journals analyzed (table 5). It is more interesting to discover that almost all authors listing two occupations (4.3 percent of all data entries) are special librarians (102 of 119). Most teach either in the institution with which their library is associated-most often a law or medical school-or in a library school. This dual occupation category includes 8.7 percent of the special library authors.

Library science faculty members contributed 20.1 percent of the articles in the Olsgaard study, as compared to a contribution of only 10.3 percent of the articles in special library journals. This statistic lends support to the authors' belief that the Olsgaards sampled journals of interest to the academic library community.

While no exact comparisons are possible because of redefinition of occupational categories, "practicing librarians" appear to be published to about the same extent in special library journals as in those surveyed by the Olsgaards. This statement is based on a comparison of the "academic," "public," and "other" librarian categories in the Olsgaard study (47.2 percent of the population studied) with the "academic" and "special" librarian categories in this study (47.4 percent of the total population analyzed, see table 6).*

As might be expected, the three "traditional" special library journals studied, Law

*The "other librarian" category in this study is not included because it also contains library science students. 
TABLE 6

Comparative Occupational Ratios

\begin{tabular}{lr}
\hline \hline Olsgaard Study & \\
Academic librarians & $30.1 \%$ \\
Public librarians & $10.0 \%$ \\
Other librarians & $7.1 \%$ \\
Library science faculty & $20.1 \%$ \\
Library science students & $2.8 \%$ \\
Other faculty & $7.1 \%$ \\
Nonlibrarian/Nonacademic & $22.7 \%$ \\
& \\
Special Library Study & \\
Special librarians & $41.6 \%$ \\
Academic librarians & $5.8 \%$ \\
Library science faculty & $10.3 \%$ \\
Other librarians/Library science students & $3.3 \%$ \\
Other faculty/Graduate students & $19.1 \%$ \\
Information suppliers/Brokers/Associations & $4.7 \%$ \\
Nonlibrary/Government/Private sector & $15.3 \%$ \\
\hline
\end{tabular}

TABLE 7

Practicing Librarians in Five Special Library Periodicals

\begin{tabular}{ll}
\hline \hline ASIS & At least $8.3 \%$ \\
Law & At least $64.1 \%$ \\
MLA & At least $71.2 \%$ \\
Online & At least $35.0 \%$ \\
SL & At least $57.4 \%$ \\
\hline
\end{tabular}

Library Journal, Bulletin of the Medical Library Association, and Special Libraries, exhibit higher percentages of authorship by "practicing librarians" than do their crossdisciplinary counterparts (table 7).*

\section{Conclusions}

The authors set out to test the Olsgaards' profile of authorship in library periodicals against another sample population to assure its validity and applicability to the whole library community. While this study revealed some small differences from the Olsgaard model, it is perhaps more remarkable in its similarities, including the disturbing underrepresentation of female authors in all journals studied (see figure 2).

It is beyond the scope of this study to analyze the causes of this apparent imbalance; however, the authors believe that it is a matter for concern, discussion, and further research, not only by librarians but

*"Practicing librarians" includes the academic and special librarian categories. also by psychologists and sociologists. Among the questions that might be raised in relation to this apparent imbalance are:

1. Do female authors submit fewer articles for publication?

2. Are female librarians less careeroriented and consequently less willing to undertake extracurricular research?

3. Are male librarians more likely to be found at higher organizational levels, which encourage the expression of opinions in public forums?

By merging the statistics generated by this study with those of its predecessor, a refined profile of authorship in library periodicals emerges. The typical author writing in a library science journal is still a male from the northeastern United States who is actively employed as a librarian, but the disparity between male and female authorship is somewhat less than that indicated by the Olsgaard study. The refined profile is summarized in figures 2 and 3 and table 8.

Combined studies

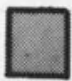

Weighted average of academic and special librarians

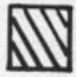

8()

70

60)

50

40

30

20

10

()

29.3 60.9

70.7

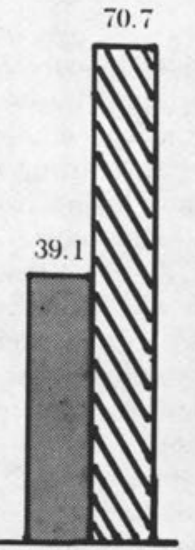

Percentage Male Percentage Female

Fig. 2

Gender Ratios-Publishing Librarians Combined Studies and National Average of Librarians 


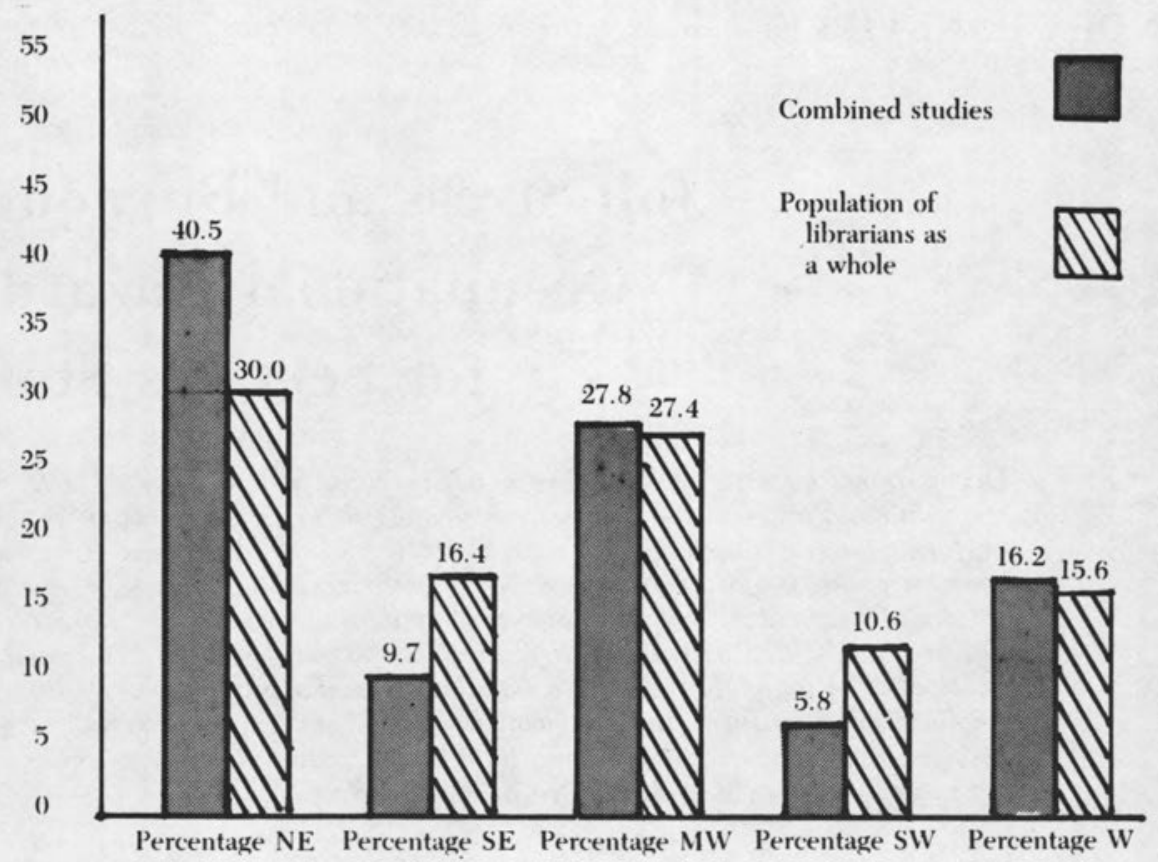

Fig. 3

Geographic Distribution-Publishing Librarians

Combined Studies and U.S. Population of Librarians

TABLE 8

Occupation Combined Studies

Library science faculty

Practicing librarians $14.8 \%$ At least $47.3 \%$

Surveys like the two discussed here are just the beginning of much needed work on the bibliometrics of library science. Still unexplored are the publishing characteristics of school and public librarians and of important subject specialties within the library profession. Also yet to be investigated are more complex bibliometric patterns, such as how ideas travel among library professionals.

\section{REFERENCES}

1. John N. Olsgaard and Jane K. Olsgaard, "Authorship in Five Library Periodicals," College \& Research Libraries 41:49-53 (Jan. 1980).

2. Ibid., p.51.

3. Ibid., p. 49.

4. Ibid.

5. "Graduate Library School Programs Accredited by the American Library Association (December 1978)," The ALA Yearbook 1979 (Chicago: American Library Assn., 1979), p.10-11. 